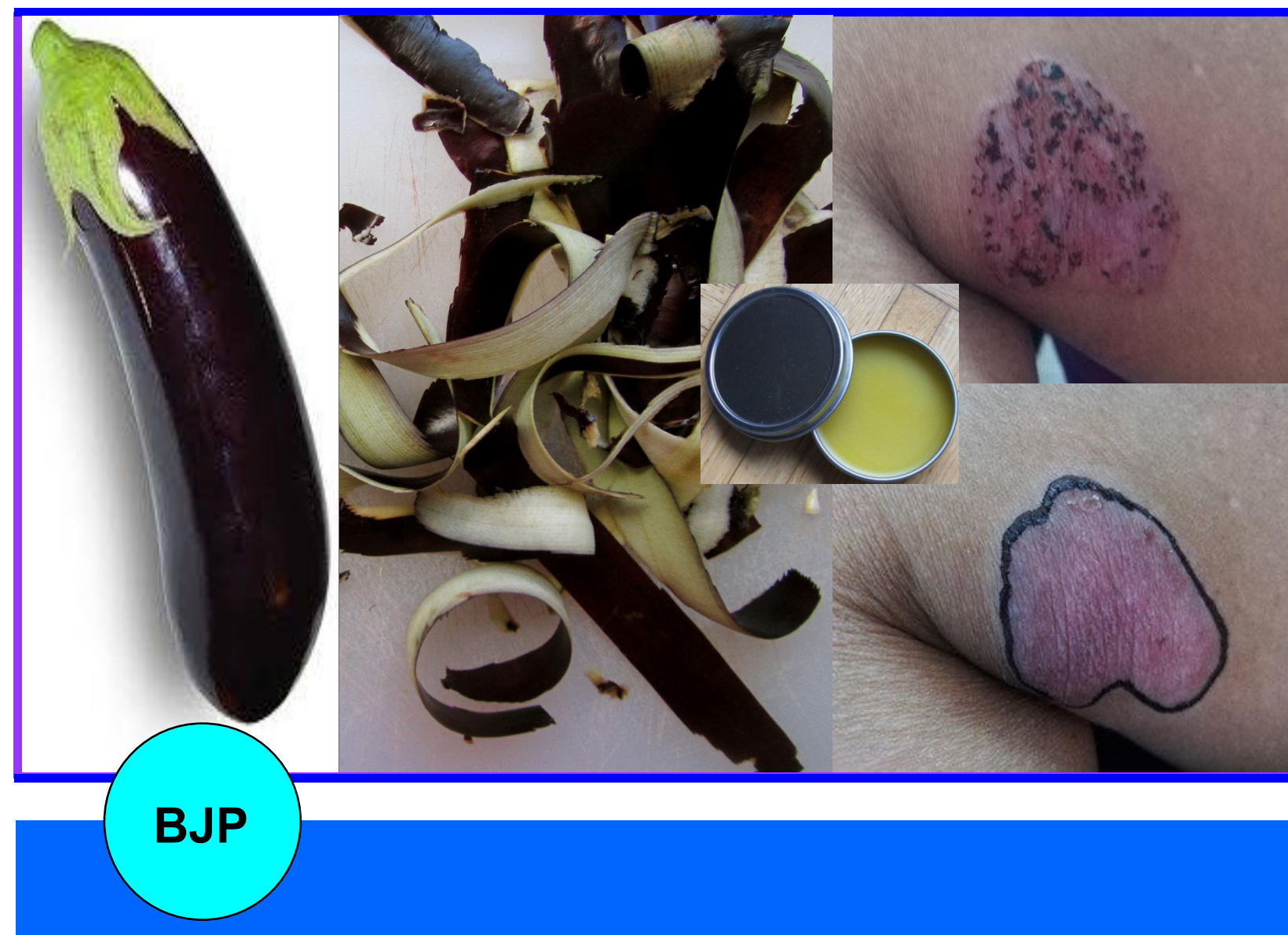

Bangladesh Journal of Pharmacology

Clinical Trial

Effect of Solanum melongena peel extract in the treatment of arsenicinduced Bowen's disease 


\section{Effect of Solanum melongena peel extract in the treatment of arsenic-induced Bowen's disease}

\section{Quazi Sahely Sarah and Mir Misbahuddin}

Division of Arsenic Research, Department of Pharmacology, Faculty of Basic Science and Paraclinical Science, Bangabandhu Sheikh Mujib Medical University, Shahbag, Dhaka, Bangladesh.

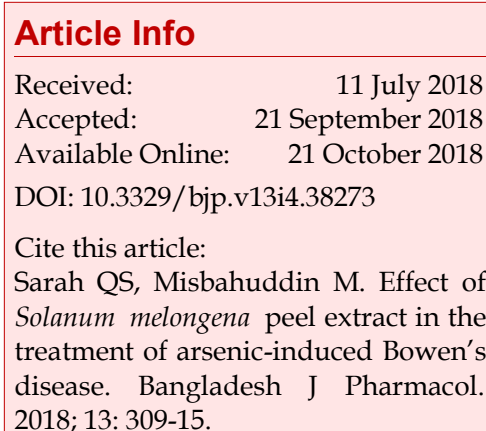

\begin{abstract}
The aim of this study was to see the effectiveness of Solanum melongena peel extract in the treatment of arsenic-induced Bowen's disease. In total 8 patients of arsenic-induced Bowen's disease were selected from the two arsenicendemic areas. The peel extract containing ointment was provided to each patient and instructed him/her to apply twice daily on the site of the lesion for 12 weeks. The measurement of the lesion size as well as photograph were collected both before and at the end of the study. The mean $( \pm \mathrm{SD})$ diameter of the lesion was $3.8 \pm 1.9 \mathrm{~cm}$ which reduced to $2.5 \pm 1.7 \mathrm{~cm}$ (reduction $34 \%$ ). The result was statistically significant.
\end{abstract}

\section{Introduction}

Arsenicosis is a chronic medical condition caused by the ingestion of arsenic contaminated water $(>50 \mathrm{ppb})$ for more than six months (Misbahuddin, 2015). The common skin manifestations are melanosis and keratosis (Caussy, 2005). Some patients also suffer from Bowen's disease (Yu et al., 2001 and Lee et al., 2004). It is a squamous cell carcinoma in situ. Bowen's disease may be due to arsenic or non-arsenic-induced.

The published results show the treatment options of non-arsenic-induced Bowen's disease are cryotherapy, curettage with cautery, excision, 5-fluorouracil, radiotherapy, laser, photodynamic therapy, imiquimod, etc. Topical diclofenac and topical imiquimod and photodynamic therapy are also recommended (Neubert and Lehmann, 2008). None of the options has been claimed to be superior to the other. Each procedure has advantages and disadvantages. However, the recurrence rate is high. Acitretin was reported to treat the arsenicinduced Bowen's disease (Yerebakan et al., 2002).

Skin cancer can be treated with several plants like Camelia sinensis (Kumari et al., 2017), Solanum melongena
(Cham et al., 1991), Solanum nigrum (Al Sinani et al., 2016), Sylibum marianum (Tsai et al., 2015), Polygonum cuspidatum (Ali and Braun, 2014), Plumbago zeylanica (Checker et al., 2010), etc.

So, the present study was carried out to see whether $S$. melongena peel extract was effective in the treatment of arsenic-induced Bowen's disease.

\section{Materials and Methods}

The total duration of the study was 17 months (from September 2016 to January 2018).

\section{Place of the study}

Two arsenic affected endemic areas were selected: a) Hamirdi Union, Bhanga Upazilla, Faridpur District and b) Sirajdikhan Upazilla of Munshiganj District. Bhanga Upazilla is about $150 \mathrm{~km}$ from Dhaka whereas Sirajdikhan Upazilla is about $25 \mathrm{~km}$ from Dhaka.

The laboratory of the Department of Pharmacology was used to a) estimate the amount of arsenic present in the participant's drinking water and nail; b) collect the $S$. 
melongena peel and to prepare the extract (ethanol, chloroform and acetic acid); c) prepare the ointment containing extract; and d) brine shrimp cytotoxicity assay.

\section{Enrolment of subjects}

The present study was carried out on 8 patients (3 males and 5 females) of Bowen's disease. Four patients were from the Bhanga Upazilla and the rest 4 patients from the Sirajdikhan Upazilla. They voluntarily agreed to participate in this study. They were enrolled according to the inclusion and exclusion criteria. The inclusion criteria were a) subjects aged $>18$ or $<65$ years of both sex; b) consumption of high concentration of arsenic water (>50 $\mu \mathrm{g} / \mathrm{L})$ for more than 6 months; c) Bowen's disease; and d) arsenicosis patient voluntarily agreed to participate. The exclusion criteria were a) pregnant and lactating mother; b) any drug allergy, or food allergy specially S. melongena; and c) patient who received any of arsenicosis treatment within the last three months.

Each patient was advised to attend the Temporary Arsenic Clinic. Clinical examination of the patient and distribution of ointment containing extract were done at two weeks interval.

\section{Participant's data collection procedure}

Detailed history, clinical examination, photographs and tracing diagram of the Bowen's disease areas were collected. Drinking water and nail were collected for estimation of arsenic in the samples. The appropriate instruction was given to them, how to apply $S$. melongena extract containing ointment at the Bowen's disease lesion areas.

\section{Measurement of the size of the lesion}

The size of the Bowen's disease lesions was measured both before starting the treatment (day 0) and after completion of treatment (day 85).

\section{Box 1: Extraction procedure}

\section{Requirements}

Acetic acid, chloroform, cheese-cloth, ethanol, round bottom flask, S. melongena, vacuum rotary evaporator, Whatman filter paper

\section{Procedure}

Step 1: Collection of S. melongena $(2 \mathrm{~kg})$ from the local market

Step 2: Separate the purple color skin form the pulp of the $S$. melongena, made them into small pieces and dry them at room temperature avoiding the sun light

Step 3: Add $65 \%$ ethanol, $32 \%$ of chloroform and $3 \%$ acetic acid in an amber colored container $(2.5 \mathrm{~L})$

Step 4: Immersed the dried peel into the solvent for 72 hours

\section{Collection of samples}

The water sample as well as the nails (grown in one month) were collected for the estimation of the total arsenic level once before starting the treatment. The purpose was to confirm the diagnosis.

One polyethylene container containing one drop of nitric acid (100 mL size) was supplied to each patient to collect the water sample that was used by himself/ herself. All these samples were collected and transported to the Pharmacology lab and stored until analysis.

The patient's hand and toe nails (growth in one month) were collected (at least $200 \mathrm{mg}$ ) and stored in a supplied leveled plastic bag. All the nail samples were collected and transported to the lab and stored until analysis.

\section{Estimation of arsenic}

The level of arsenic in the drinking water and nail was measured by silver diethyldithiocarbamate (SDDC) method (Bhuiyan et al., 2015).

\section{Method of S. melongena extraction (Box 1)}

There are three botanical varieties of eggplant-based on the shape of the fruit (Niño-Medina et al., 2017). These are a) egg-shaped (S. melongena var. esculentum), b) long and slender in shape (S. melongena var. serpentinum) and c) dwarf types (S. melongena var. depressum).

The fruit was identified and authenticated by Mr. Khandokar Kamrul Islam, Scientific Officer, Bangladesh National Herbarium, Dhaka, Bangladesh.

In this study, $12 \mathrm{~kg}$ of S. melongena (size: at least 8 inches long and 1.5-2 inches breadth; skin color: purple) were collected from the local market in different time interval. These were washed and peeled off the skin from the pulp using a vegetable peeler. The peels were cut into small pieces. The rest of the S. melongena were discarded. The pieces of peels of $S$. melongena were then air-dried at room temperature.

Step 5: Separate the solid parts from the solvent by using cheese-cloth

Step 6: The solvent was filtered using Whatman 102 filter paper

Step 7: Filtrate was collected at round bottom flask and fitted it to vacuum rotary evaporator for the evaporation

Step 8: Condensation of filtrate in a vacuum rotary evaporator, rotation about $100 / \mathrm{min}$ at $60^{\circ} \mathrm{C}$

Step 9: Collection of condensed extract in an amber color glass container and preserved at $4^{\circ} \mathrm{C}$ until ointment preparation

Precaution

Protect the extract from exposure to light. That is why aluminum foil was used to wrap the flask containing extract during the use of rotary evaporator 
The small pieces of peel $(500 \mathrm{~g})$ were obtained and immersed into an ambered color bottle (size $2.5 \mathrm{~L}$ ) containing $2 \mathrm{~L}$ of the mixture of ethanol: chloroform: acetic acid (65: 32: 3) and keep them for 72 hours at room temperature. Then the solvent was separated from the solid parts by using Whatman 102 filter paper. The filtrate liquid was concentrated at $40-50^{\circ} \mathrm{C}$ under reduced pressure using a rotary evaporator until a dark brownish color semi-solid substance was obtained. Finally, the extract was stored in an amber color container and kept it into a refrigerator at $4^{\circ} \mathrm{C}$ until use. According to the above-mentioned procedure, $S$. melongena peel extract was prepared several times. From $4 \mathrm{~kg}$ of small pieces of S. melongena peel extract 2 g extract was obtained.

\section{Brine shrimp lethality study (Sarah et al., 2017)}

The eggs of Artemia salina (brine shrimp) were collected from the local market. A small amount of eggs (15 g) were poured into a square shaped glass vessel (capacity $=6 \mathrm{~L}$ ) containing $4 \mathrm{~L}$ of artificial seawater for hatching up to 48 hours with continuous aeration and artificial light using a 60 watt bulb. Active nauplii were free from eggshells within this period.

The S. melongena peel extract of $1 \mathrm{mg}$ was weighted by an analytical balance. Sterile test tubes were taken and leveled them. The extract (soluble in water) was dissolved in $1 \mathrm{~mL}$ of water to prepare the stock solution. Serial dilution of the stock solution was done to prepare the concentration of $100,10,1.0,0.1 \mu \mathrm{g} / \mathrm{mL}$. About $1 \mathrm{~mL}$ of the prepared solution was taken into five (I-V) labeled test tube contained actively moving 10 live nauplii in $1 \mathrm{~mL}$ of artificial seawater containing different concentrations of $S$. melongena extract.

All the test tubes were incubated at room temperature and observed the active movement of nauplii after 2 and 24 hours.

Percentage of death $=[($ No. of dead nauplii $) /($ No. of dead nauplii + No. of live $)] \times 100$

\section{Preparation of ointment containing extract}

One hundred gram of ointment contained $30 \mathrm{mg}$ of $S$. melongena peel extract. All the ingredients were accurately measured by either an electronic balance or a measuring cylinder. A bowl containing $100 \mathrm{~mL}$ of water was heated up to boiling by a gas burner. A beaker containing $90 \mathrm{~mL}$ olive oil was placed into the boiling water (Block, 2000). When the temperature of the olive oil was $90^{\circ} \mathrm{C}$, then $10 \mathrm{~g}$ of bee wax was added to it. After complete melting of the bee wax, the gas burner was put off and the beaker placed for cool down at room temperature. Then $10 \mathrm{mg}$ of benzoic acid and 30 $\mathrm{mg}$ of $S$. melongena peel extract were added and contentiously beat until it became thick. Finally, it was transferred into the plastic screw cap ointment container (20 g each) and stored in a refrigerator until distributed to the patient.

\section{Distribution of ointment}

S. melongena extract ointment was distributed to each patient and he/she was instructed to apply the ointment to the affected area of the skin by clean fingertip twice daily (at the morning and bedtime). A separate printed sheet was given for checking the compliance by giving a tick mark at the appropriate place just after applying of ointment.

\section{Periodic monitoring of patients}

Each patient attended the Temporary Arsenic Clinic every 2 weeks interval. The researcher monitored the lesion, check the adherence and note down the improvement(s). A regular communication to the patient was maintained over cell phone.

\section{Statistical analysis}

Statistical analysis was done by paired ' $t$ ' test to compare the Bowen's disease lesion size before and after the end of the treatment. Data were presented as mean \pm SD.

\section{Results}

Fifty percent of the death nauplii were found in the artificial seawater containing $100 \mu \mathrm{g} / \mathrm{mL}$ of $S$. melongena extract (Table I).

The mean $( \pm S D)$ age of the patients was $53.1 \pm 6.6$ years (Table II). The mean amount of arsenic in the tube-well water consumed by the patients was $677.3 \pm 140.1 \mu \mathrm{g} / \mathrm{L}$. The mean amount of arsenic in the nail sample was 28.3 $\pm 15.0 \mu \mathrm{g} / \mathrm{g}$. The mean duration of exposure to arseniccontaminated water was $20.9 \pm 5.8$ years. The mean duration of the appearance of the Bowen' disease lesions was $8.8 \pm 7.3$ years.

The number of drop out patients was two due to loss to follow-up. The new lesions appeared on the chest of a patient of Bowen's disease who was a smoker.

\section{Measurement of the Bowen's disease lesion size}

The size (mean \pm SD) of the lesions during the enroll-

\begin{tabular}{|cc|}
\hline \multicolumn{2}{|c|}{ Table I } \\
\hline $\begin{array}{c}\text { Numbers of death nauplii at different concentra- } \\
\text { tion of } S \text {. melongena peel extract }\end{array}$ \\
\hline $\begin{array}{c}\text { Concentration of the ex- } \\
\text { tract }(\mu \mathrm{g} / \mathrm{mL})\end{array}$ & $\begin{array}{c}\text { Percentage of death nauplii } \\
\text { at the end of } 24 \text { hours }\end{array}$ \\
\hline 0 & $10 \%$ \\
0.1 & $90 \%$ \\
1.0 & $70 \%$ \\
10.0 & $60 \%$ \\
100.0 & $50 \%$ \\
\hline
\end{tabular}




\begin{tabular}{|l|c|}
\hline \multicolumn{2}{|c|}{ Table II } \\
\hline \multicolumn{2}{|c|}{ Baseline characteristics of the patients } \\
\hline \multicolumn{2}{|c|}{ Patients } \\
\hline Age (years) & $53.1 \pm 6.6$ \\
Sex & \\
$\quad$ Male & 3 \\
Female & 5 \\
Number of smoker & \\
$\quad$ Smoker & 1 \\
$\quad$ Non-smoker & 7 \\
Tube-well water arsenic concentra- & $677.3 \pm 140.1$ \\
tion ( $\mu$ g/L) & \\
Arsenic concentration in nail $(\mu \mathrm{g} / \mathrm{g})$ & $28.3 \pm 15.0$ \\
Arsenic exposure duration (years) & $20.9 \pm 5.8$ \\
Duration of appearance (year) & $8.8 \pm 7.3$ \\
Data are mean \pm SD & \\
\hline
\end{tabular}

ment was $3.8 \pm 1.9 \mathrm{~cm}$ which was reduced to $2.5 \pm 1.7$ $\mathrm{cm}$ after 12 weeks of the topical application of ointment and the total percentage of reduction was $34 \%$ (Table III). This change was statistically significant $(\mathrm{p}=0.0003)$. There was a reduction in the elevation of the lesions (Figure 1).

During the first two weeks of topical application of ointment, the lesion became erythematous and subside after the next two weeks.

\section{Discussion}

The present study revealed the significant improvement effect in reducing the lesion of Bowen's disease. The improvement of patient's lesion was assessed by measuring lesion size. The size of the Bowen's disease lesions was 2 to $7.6 \mathrm{~cm}$ in diameter. After topical application of $S$. melongena peel extract containing ointment for 12 weeks, the percentage of reduction was statistically significant.

This is the first study showing the effect of topical application of $S$. melongena peel extract in the treatment of arsenic-induced Bowen's disease. Only 34\% improvement was shown. The effect may be more if the a) higher concentration of the extract was used, b) modification of the ointment for better penetration of the extract through the skin, c) prolonged duration of action, and d) increased frequency of administration. However, in this study, the recurrence was not observed

Table III

Measurement of Bowen's disease lesions size

\begin{tabular}{|cccc|}
\hline Patient (\#) & \multicolumn{2}{c}{ Size of the lesion size $(\mathrm{cm})$} & \multirow{2}{*}{ p value } \\
\cline { 2 - 3 } & Before study & After study & \\
\hline 1 & 4.5 & 2.7 & \\
2 & 2.0 & 0.4 & \\
3 & 2.5 & 1.5 & 0.0003 \\
4 & 7.6 & 5.9 & \\
5 & 2.2 & 1.5 & \\
6 & 2.7 & 1.9 & \\
7 & 5.0 & 3.1 & \\
8 & 3.8 & 3.2 & \\
Mean \pm SD & $3.8 \pm 1.9$ & $2.5 \pm 1.7$ & \\
Paired t-test was between before and after study to estimate the \\
level of significance of difference & \\
\hline
\end{tabular}

except one who was a smoker.

S. melongena is a vegetable. Its peel is violet in color which contains nasunin and chlorogenic acid. The
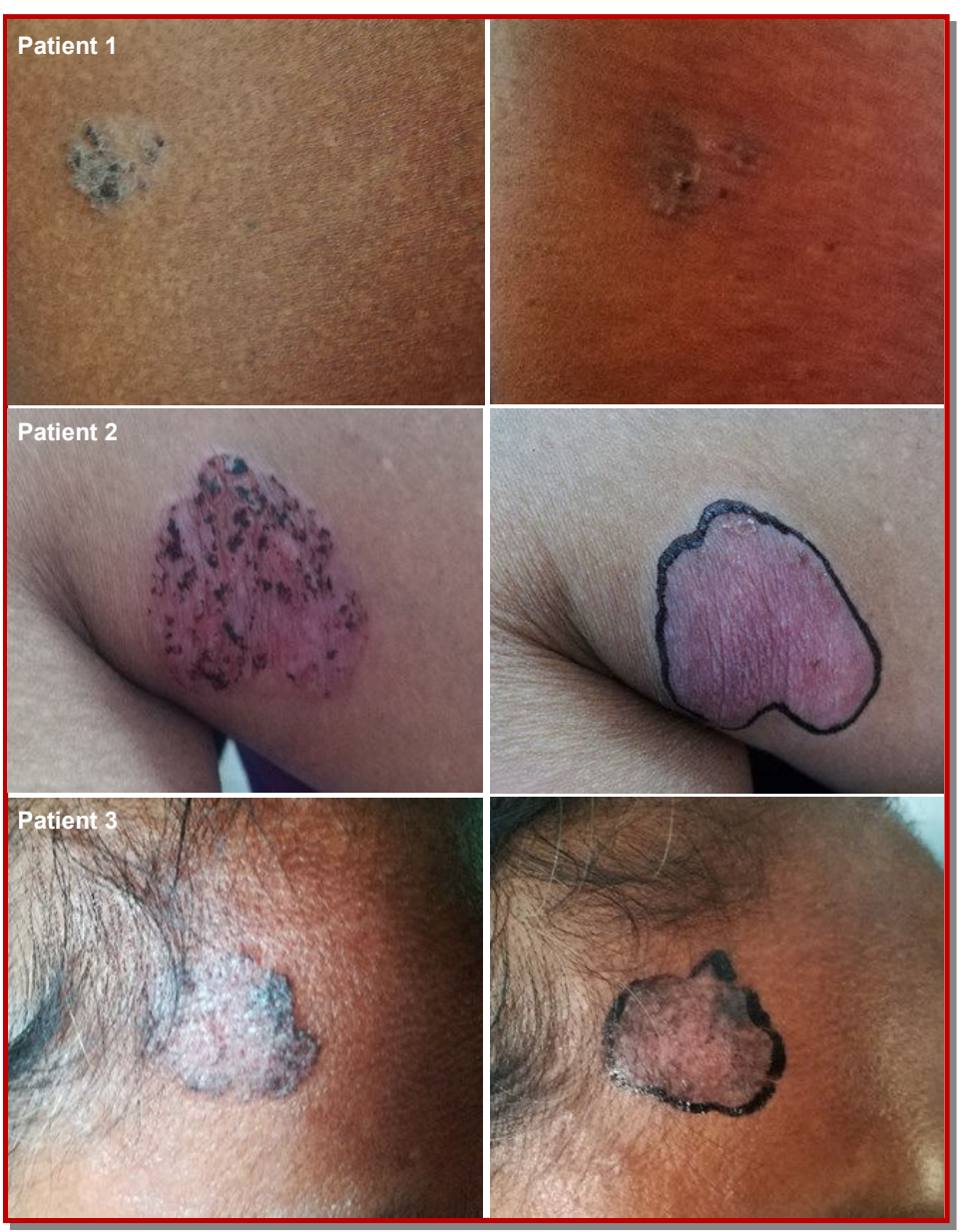

Figure 1: Photographs show the effectiveness of the extract of three patients of Bowen's disease. Left column represents before treatment and right column represents after treatment
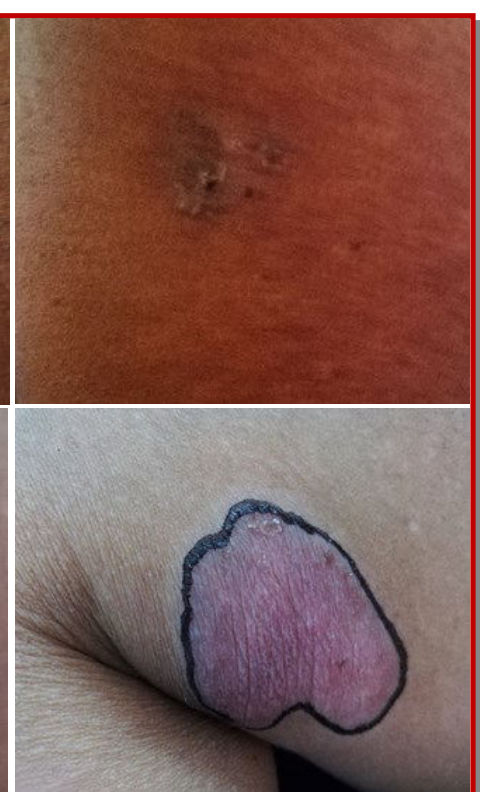
nt 
nasunin is an anthocyanin (from the Greek anthos = flower and kyano = blue), $700 \mathrm{mg}$ per $100 \mathrm{~g}$ and is responsible for the purple color of this vegetable. Both show anti-oxidant effect and can be used in aging, inflammation, cardiovascular disease, cancer (Gallo et al., 2014).

S. melongena fruit is rich in steroidal alkaloids, which were reported to possess anti-cancer activity against liver and lung cancer (Kuo et al., 2000; Liu et al., 2004). The methanol extract of the peel contains five steroidal compounds; three steroidal alkaloids: solasodine, solamargine and solasonine together with two steroidal glycosides: $\beta$-sitosterol-3-O- $\beta$-D-glucoside and poriferasterol-3-O- $\beta$-D-glucoside. These compounds exhibited moderate to potent activities against the tested human cancer cell lines colon cancer cell line (HCT116), larynx cancer cell line (HEP2), breast cancer cell line (MCF7), cervix cancer cell line (HELA) and liver cancer cell line (HEPG2) (Shabana et al., 2013).

The present study is similar to the findings of the topical application of low concentration $(0.005 \%)$ of a standard mixture of solasodine glycosides to 29 squamous cell carcinoma (skin) patients (Cham et al., 1991). There was complete regression of lesions without recurrence. This component is more specific for the malignant cells than the normal cells and the new normal cells regrow at the place of the lesion.

The solasodine glycosides are cytotoxic substances present in the S. melongena peel extract and able to kill cancer cells. The plasma membrane of the susceptible cancer cells expresses specific endogenous endocytic lectins that bind to the sugar moiety of the solasodine glycosides and induces cell death by lysis of the targeted tumor cells. It is harmless for normal cells due to the absence of endogenous endocytic lectins.

A study explained the mode of action of solamargine as a potent cytotoxic activity against tumor cells by initiate a death process named oncosis. It also displays an unusual mode of action thus it avoids the common multidrug resistant mechanism (Sun et al., 2011).

Nasunin is an anthocyanin of the S. melongena peel extract showed biological abilities to prevent the production of free radicals, induces apoptosis, inhibits cell proliferation and angiogenesis.

One study was conducted in the two arsenic-induced Bowen's disease patients treated with acitretin $(1 \mathrm{mg} /$ $\mathrm{kg}$ ) daily (Yerebakan et al., 2002). The total cure was obtained in case of the first patient after 10 months but another patient discontinued the treatment after five months due to symptomatic adverse effects like hearing loss, insomnia and joint pain.

A patient with arsenic-induced keratoses and Bowen's disease responded well to acitretin (Watson and Creamer, 2004).
Acitretin is a retinoid analog (vitamin A). It works by inhibiting the excessive cell growth and keratinization. It, therefore, reduces the thickening of the skin, plaque formation and scaling. S. melongena peel extract containing solasodine glycosides which induced apoptosis of the cells by up-regulation of tumor necrosis factor and Fas receptor. Also decrease the $\mathrm{Bcl} 2$ expression concomitant increase protein level of Bax which collectively activation of the intrinsic and extrinsic pathway of apoptosis through caspase $-8,-9$ and -3 .

Forty one patients of non-arsenic-induced Bowen's disease were treated with topical 5-fluorouracil for 4-12 weeks (Sturm, 1979). The concentration of 5-fluorouracil was $1 \%$ for the face area and $2.5-3 \%$ for other areas of the body. After treatment (three patients recur), $8 \%$ recurrence occurred which was retreated with the same medication. But the main limitation was the prolonged treatment period with the recurrent application of medicine and skin irritation with burning sensation and discoloration of the affected site.

5-Fluorouracil is a pyrimidine analog that irreversibly binds within a cell to thymidylate synthetase. This prevents the incorporation of uracil into nuclear RNA, which destroys abnormal cancer cells. It acts nonspecifically both in cancer and normal cells.

Another study conducted with 16 patients of Bowen's disease (not arsenic-induced) applied the topical 5\% imiquimod cream (Mackenzie-Wood et al., 2001). In that study, showed clinical improvement in ten patients after 16 weeks of treatment and the rest of six patients discontinued the treatment due to irritation, skin rash and erythema of the local skin.

Imiquimod cream (5\%) is an immunomodulator which stimulates the local cytokines thus regression and normalization of the normal keratinocytes (Tyring et al., 1998).

The study of comparison of photodynamic therapy with topical 5-fluorouracil in Bowen's disease showed that $88 \%$ initial complete clearance rate with photodynamic therapy and $67 \%$ complete cured with 5fluorouracil (Salim et al., 2003). Follow-up at 12 months, photodynamic therapy group recurrences were two and six in 5-fluorouracil group. No adverse reaction was observed in photodynamic therapy-treated patients. On the other hand, three patients develop widespread dermatitis, one patient develops ulceration with painful erosions during the medication period. The photodynamic therapy is costly and may need more than one session.

Another study with methyl aminolevulinate with photodynamic therapy (MAL-PDT) when compared with placebo-PDT or cryotherapy (Bath-Hextall et al., 2013) demonstrate statistically significant but the cryotherapy shows recurrence at one year with no statistically significant difference in clearance rate when 
compared with the 5-fluorouracil in Bowen's disease. Cryotherapy is painful and the skin may be uncomfortable for a few weeks.

\section{Conclusion}

S. melongena extract containing ointment has significant beneficial effect in the treatment of Bowen's disease.

\section{Ethical Issue}

The protocol was approved by the Institutional Review Board of Bangabandhu Sheikh Mujib Medical University (Reg. No. BSMMU/2017/ 3322). This work was registered on the clinical trial.gov (Registration number was NCT 03122561).

All the participants were informed about the objective, potential hazards, benefits and outcome of this study. All the information was explained in an easy and local language (Bengali). Informed consent was taken in a consent-form with either participant's thumb impression or signature.

All the participants were monitored and looked after carefully. Whether any complication arises during this treatment period, they had under careful observations and the researcher agreed to organize the symptomatic treatment.

\section{Conflict of Interest}

Authors declare no conflict of interest.

\section{Acknowledgement}

We are grateful to the villagers of Monsurabad Union of Bhanga Upazilla of Faridpur District and Sirajdikhan Upazilla of Munshiganj District, for participating actively in this study. We are also grateful to Upazilla health and family planning officer of Bhanga Dr. Md. Abdullah and Dr. Dulal Hossain of Sirajdikhan Upazilla Health Complex. Also thanks to the community health care provider Mr. Md. Safique and health inspector Mr. Md. Habibur Rahman.

\section{References}

Al Sinani SS, Eltayeb EA, Coomber BL, Adham SA. Solamargine triggers cellular necrosis selectively in different types of human melanoma cancer cells through extrinsic lysosomal mitochondrial death pathway. Cancer Cell Int. 2016; 16: 11

Ali I, Braun DP. Resveratrol enhances mitomycin C-mediated suppression of human colorectal cancer cell proliferation by up-regulation of p21WAF1/CIP1. Anticancer Res. 2014; 34: 5439-46.

Bath-Hextall FJ, Martin RN, Wilkinson D, Lonardi-Bee J. Interventions of cutaneous Bowen's disease. Cochrane Database of Systemic Reviews. 2013, p 6.
Bhuiyan HA, Tshering K, Misbahuddin M. Estimation of arsenic in nail using silver diethyldithiocarbamate method. Bangladesh J Pharmacol. 2015; 10: 513-17.

Block LH. Ointments. In: Remington: The science and practice of pharmacy. Gennaro AR (ed). 20th ed. Vol 1. 2000, pp 84546.

Caussy D. A field guide for detection, management and surveillance of arsenicosis cases. New Delhi, WHO Regional Office for South-East Asia, 2005.

Cham BE, Daunture B, Evans RA. Topical treatment of malignant and premalignant skin lesion by very low concentrations of standard mixture (BEC) of solasodine glycosides. Cancer Lett. 1991; 59: 183-92.

Checker R, Sharma D, Sandur SK, Subrahmanyam G, Krishnan S, Poduval TB, Sainis KB. Plumbagin inhibits proliferative and inflammatory responses of $\mathrm{T}$ cells independent of ROS generation but by modulating intracellular thiols. J Cell Biochem. 2010; 110: 1082-93.

Gallo M, Naviglio D, Ferrara L. Nasunin, an antioxidant anthocyanin from eggplant peels, as natural dye to avoid food allergies and intolerances. Eur Sci J. 2014; 10.

Kumari M, Pattnaik B, Rajan SY, Shrikant S, Surendra SU. EGCG-A Promis anti-cancer. Phytochemistry 2017; 3: 8-10.

Kuo KW, Hsu SH, Li YP, Lin WL, Liu LF, Chang LC, Lin CC, Lin $\mathrm{CN}$, Sheu HM. Anticancer activity evaluation of the solanum glycoalkaloid solamargine: Triggering apoptosis in human hepatoma cells. Biochem Pharmacol. 2000; 60: 186573.

Lee $\mathrm{CH}, \mathrm{Yu} \mathrm{CL}$, Liao WT. Effects and integrations of low doses of arsenic and UVB on keratinocyte apoptosis. Chem Res Toxicol. 2004; 17: 1199-205.

Liu LF, Liang CH, Shiu LY, Lin WL, Lin CC, Kuo KW. Action of solamargine on human lung cancer cells: Enhancement of the susceptibility of cancer cells to TNFs. FEBS Lett. 2004; 577: 67-74.

Mackenzie-Wood A, Kossard S, Launey J, Wilkinson B, Owens ML. Imiquimod $5 \%$ cream in the treatment of Bowen's disease. J Am Acad Dermatol. 2001; 44: 462-70.

Misbahuddin M. Arsenicosis: A global issue. New York, Science Publishing Group, 2015, pp 1-204.

Niño-Medina G, Urías-Orona V, Muy-Rangel MD, Heredia JB. Structure and content of phenolics in eggplant (Solanum melongena): A review. South Afr J Bot. 2017; 111: 161-69.

Neubert T, Lehmann P. Bowen's disease: A review of newer treatment options. Ther Clin Risk Manag. 2008; 4: 1085-95.

Salim A, Leman J, Mccoll JH, Chapman R, Morton CA. Therapeutics randomized comparison of photodynamic therapy with topical 5-flurouracil in Bowen's Disease. Br J Dermatol. 2003; 148: 539-43.

Sarah Q, Anny F, Misbahuddin M. Brine shrimp lethality assay. Bangladesh J Pharmacol. 2017; 12.

Shabana MM, Salama MM, Ezzat SM, Ismail LR. In vitro and in vivo anticancer activity of the fruit peels of Solanum melongena L. against hepatocellular carcinoma. J Carcinog 
Mutagen. 2013; 4: 149-54.

Sturm HM. Bowen's disease and 5-fluorouracil. J Am Acad Dermatol. 1979; 1: 513-22.

Sun L, Zoha Y, Yuan H, Li X, Cheng A, Lou H. Solamargine, a steroidal alkaloid glycoside, induces oncosis in human K562 leukemia and squamous cell carcinoma KB cells. Cancer Chemother Pharmacol. 2011; 67: 813-21.

Tsai CC, Chuang TW, Chen LJ, Niu HS, Chung KM, Cheng JT, Lin KC. Increase in apoptosis by combination of metformin with silibinin in human colorectal cancer cells. World J Gastroenterol. 2015; 21: 4169-77.
Tyring SK, Arany II, Stanley MA, Stoler MH, Tomai MA, Miller RL, Owens ML, Smith MH. Mechanism of action of imiquimod 5\% cream in the treatment of anogenital warts. Primary Care Update for OB/ GYNS. 1998; 5: 151-52.

Watson K, Creamer D. Arsenic-induced keratoses and Bowen's disease. Clin Exper Dermatol. 2004; 29: 46-48.

Yerebakan O, Ermis O, Yilmaz E, Basaran E. Treatment of arsenical keratosis and Bowen's disease with acitretin. Int J Dermatol. 2002; 41: 84-87.

$\mathrm{Yu}$ HS, Lee $\mathrm{CH}$, Jee SH, Ho CK, Guo YL. Environmental and occupational skin diseases in Taiwan. J Dermatol. 2001; 28: 628-31. 